\title{
Characterization of Wastewater Used for Irrigation and Other Purposes in Chad
}

\author{
Gamar Mahamat Gamar ${ }^{1}$, Izzat Mirgani Taha ${ }^{2}$, Mohagir Ahmed Mohammed ${ }^{3, *}$ \\ ${ }^{1}$ Higher Institute for Teachers Formation in N'Djamena, N'Djamena, Chad \\ ${ }^{2}$ National Center for Research, Khartoum, Sudan \\ ${ }^{3}$ Faculty of Pure and Applied Science, University of N'Djamena, N'Djamena, Chad
}

Email address:

amohagir2003@yahoo.fr (M. A. Mohammed), amohagir67@gmail.com (M. A. Mohammed)

${ }^{*}$ Corresponding author

To cite this article:

Gamar Mahamat Gamar, Izzat Mirgani Taha, Mohagir Ahmed Mohammed. Characterization of Wastewater Used for Irrigation and Other Purposes in Chad. American Journal of Applied Chemistry. Vol. 9, No. 5, 2021, pp. 131-137. doi: 10.11648/j.ajac.20210905.12

Received: August 17, 2021; Accepted: September 8, 2021; Published: September 16, 2021

\begin{abstract}
This research work was based on recommendations of a number of researchers stating that pollution has appeared in the Chadian capital, N'Djamena, as a result of the liquid waste being thrown out from some private and public sectors before being treated. This study is a follow-up to research, some of which have been published and some not yet completed. The current article was focused on the determination of some physicochemical characteristics of wastewater in the capital of Chad N'Djamena and to assess their environmental impact. These characteristics were: Temperature, $\mathrm{pH}$, electrical conductivity, TDS, $\mathrm{Cu}, \mathrm{Zn}, \mathrm{Al}, \mathrm{Fe}, \mathrm{Mn}, \mathrm{NO}_{3}^{-}, \mathrm{PO}_{4}{ }^{3-}, \mathrm{HCO}_{3}^{-}$, chemical oxygen demand (COD), biological oxygen demand (BOD) and total dissolved solids. Samples were taken from four different effluent streams and analyzed according to the standard methods. The results of the evaluation were: $\mathrm{pH}(4.26 \pm 0.06-8.57 \pm 0.06)$, temperature $\left(23.17 \pm 0.21-33.60 \pm 0.10^{\circ} \mathrm{C}\right)$, electrical conductivity [EC] $(212 \pm 0.01-1997 \pm 10 \mu \mathrm{s} / \mathrm{cm})$, the total dissolved solids TDS $(1.42 \pm 0.01-906.63 \pm 1.21 \mathrm{mg} / \mathrm{l})$, chemical oxygen demand COD (30 - $1170 \mathrm{mg} / \mathrm{L})$, biological oxygen demand BOD $(26-228 \mathrm{mg} / \mathrm{L}), \mathrm{Cu}(0.11-6.20 \mathrm{mg} / \mathrm{L}), \mathrm{Zn}(0.02-$ $3.53 \mathrm{mg} / \mathrm{L}), \mathrm{Mn}(0.003-6.77 \mathrm{mg} / \mathrm{L}), \mathrm{Al}(0.10-1.12 \mathrm{mg} / \mathrm{L})$, Fe $(0.39-3.43 \mathrm{mg} / \mathrm{L})$, bicarbonate $(23.67-853.33 \mathrm{mg} / \mathrm{L})$, phosphate $(0.023-333.67 \mathrm{mg} / \mathrm{L})$ and nitrate $(0.98-127.0 \mathrm{mg} / \mathrm{L})$. These results revealed that the values of some parameters are exceeded the limit recommended by the World Health Organization for wastewater discharge. We conclude that this untreated wastewater are sources of pollution to the daily consumed legumes and vegetables.
\end{abstract}

Keywords: Effluent, Wastewater, Physicochemical Characteristics, Pollution, Chad

\section{Introduction}

Wastewater generally contains liquid wastes produced by households, hospitals, restaurants, industries, etc., as a result of daily activities. Municipal treatment facilities are designed to treat raw wastewater to produce a liquid effluent of suitable quality that can be disposed to the natural surface waters with minimum impact on environment and human health. In developed countries, much of the wastewater is treated prior to use for irrigation of fodder, fiber, and other crops. Meanwhile, though standards are set in developing countries, they are not always respected [1-3].

Pollution caused by wastewater represents the greatest threat to the sustainable use of ground and surface water.
Waste effluents and raw untreated sewage are often discharged into an open and fresh water sources. In most of developing countries, majority of rural and urban peoples discharge their raw domestic wastewater directly into the water streams without any- reservations [4]. This practice constitutes pools of wastewater in open gutters and on roads often provides breeding conditions for mosquitoes and medium for several bacteria and viruses. These observations were also reported by some authors in Chad [5-8]. Wastewater pools, contain hazardous contaminants such as oil and grease, pesticides, ammonia, and heavy metals [9]. Global climate change impacts also could tend to increase the diffuse pollution in an urban or agricultural area. The climate change determinants affecting water quality are mainly the ambient temperature and the increase 
of extreme hydrological events. Moreover, drying-rewetting soil cycles and the increase in solar radiation also could be considered [10].

Nowadays, the availability of good quality water even for human uses is threatened in many places. Consequently, irrigated agriculture faces the problem of using water of poor quality to irrigate lands that provide food for an expanding population [11]. The use of untreated wastewater in irrigated agriculture has potential for both positive and negative environmental consequences [12]. However, irrigation of agriculture with treated municipal wastewater is highly encouraged [13] and is considered as an environmentally wastewater disposal practice compared to its direct disposal to the surface or ground water. Although wastewater is a suitable source of plant nutrients and organic matter, it could contain undesirable chemical compounds and pathogens that cause negative environmental and health problem [14]. A number of risk factors have been identified in wastewater reuse, like microbial pathogens and the salinity of soil. For optimum use of wastewater for irrigation purposes, many guidelines have been developed to give a quality criteria and treatment guidance [15-16].

Contaminants in domestic wastewaters can be divided into three categories: suspended solids, organic matters (chemical oxygen demand, biochemical oxygen demand) and nutrients (nitrogen and phosphorus) [17]. A conventional wastewater treatment processes often begin by physical process and followed by biological one. In general, organic and inorganic substances in the domestic sewage may include both suspended and dissolved fractions. Suspended fraction can be easily removed by physical or physiochemical processes under most conditions. However, some dissolved substances may attach on to the suspended particles. Therefore, as long as the suspended particles can be effectively removed, the originally dissolved matter may also be removed substantially [18].

Since different water quality parameters need to be considered when evaluating wastewater effluents as a potential irrigation water source than those considered for its direct discharge into a receiving stream, a specific set of wastewater quality reporting requirements must be outlined and defined. Therefore, before using wastewater for irrigation as a means of increasing water supply for agriculture, a thorough analysis must be undertaken for a sustainable development strategy [19].

Although many research efforts have been reported in wastewater in Chad [20-21], untreated municipal wastewater in many quarters of N'Djamena city still used carelessly for the irrigation of daily consumed legumes and vegetables without any official awareness. How safe is this practice? Hence, the objective of this paper is to provide a review of the characteristics of wastewater used for irrigation and to carry out some physical and chemical characterizations of wastewater used to irrigate legumes and vegetables consumed daily in N'Djamena and evaluate their environmental impact.

\section{Materials and Methods}

\subsection{Study Location}

The location of study is N'Djamena, the capital of Chad. $\mathrm{N}^{\prime}$ Djamena locates at latitude $12.8^{\circ} \mathrm{N}$ and $15.2^{\circ} \mathrm{E}$ longitudinal at an elevation of $295 \mathrm{~m}$ above the mean sea level. The main discharge channel "la Cevette de Saint Martin" is located in the middle of the town, it is a wide but not deep, it runs from northeast to southwest and drains into Chari River. The population of N'Djamena is about 993492 habitats, distributed in 10 municipals. The study site included 4 locations; Diguel Ryad (DR) quarter in the municipal number 8 (Site 1), Paris Congo (PC) quarter in the municipal number 7 (Site 2), General Hospital channel (HGRN) in the municipal number 3 (Site 3) and the Chadian Brewery Company (STB) channel, Farcha quarter, in the municipal number 1 (Site 4).

\subsection{Water Sampling and Analysis}

The wastewater samples were collected during the season of 2014 from the 4 locations. Three samples per month from each location were collected at the same time (8:00 to 10:00 am) in a clean sterile plastic container and stored at $4^{\circ} \mathrm{C}$ in the Laboratory of Analysis of Water and Environment, Faculty of Pure and Applied Science, University of N'Djamena.

\subsection{Methodology}

Temperature $\left({ }^{\circ} \mathrm{C}\right)$ and electrical conductivity $(\mu \mathrm{m} / \mathrm{S})$ were measured using multifunction apparatus (WTW 315 i/SET) [22]. $\mathrm{pH}$ was measured using $\mathrm{pH}$ meter (ECOSCAN $\mathrm{pH}$ 6), ISO (2006) [23]. Total Dissolved Solids ( $\mathrm{mg} / \mathrm{l})$ were measured following the standard method [24]. Biological Oxygen Demand (BOD) (mg/l) and Chemical Oxygen Demand (COD) $(\mathrm{mg} / \mathrm{l})$ were estimated form incubation at $20^{\circ} \mathrm{C}$ for 5 days. Five heavy metal $(\mathrm{Cu}, \mathrm{Zn}, \mathrm{Al}, \mathrm{Fe}, \mathrm{Mn})$ and three ions $\left(\mathrm{NO}_{3}^{-}, \mathrm{PO}_{4}{ }^{3-}\right.$, $\mathrm{HCO}_{3}{ }^{-}$) were analyzed using a spectrophotometer of mark (HACH DR/2400) at different wavelengths [25].

\subsection{Statistical Analysis of Data}

The data obtained were analysed using the analyses of variance (ANOVA) at a probability $(P)$ of 0.01 and 0.05 confidence level. SPSS was used for the one-way analysis of variance (SPSS). Figures were plotted applying multiple regression analysis in Sigmaplot software (Sigmaplot $\AA$, 2010).

\section{Results and Discussion}

\subsection{Hydrogen Ion (pH)}

The results in figure 1 showed that all the values of $\mathrm{pH}$ of wastewater in the 4 locations aren't exceed the limits (6-9) recommended by WHO [14]. In location 3 (HGRN), for example, the $\mathrm{pH}$ range between $4.40 \pm 0.13$ in November to $8.40 \pm 0.08$ in September. In location 4 (STB) the highest $\mathrm{pH}$ $(8.57 \pm 0.06)$ was recorded in September, while the lowest was found to be $4.26 \pm 0.06$ in November. The high value of $\mathrm{pH}$ in location 4 could be attributed to the nature of the 
wastewater of the Chadian Brewery Company.

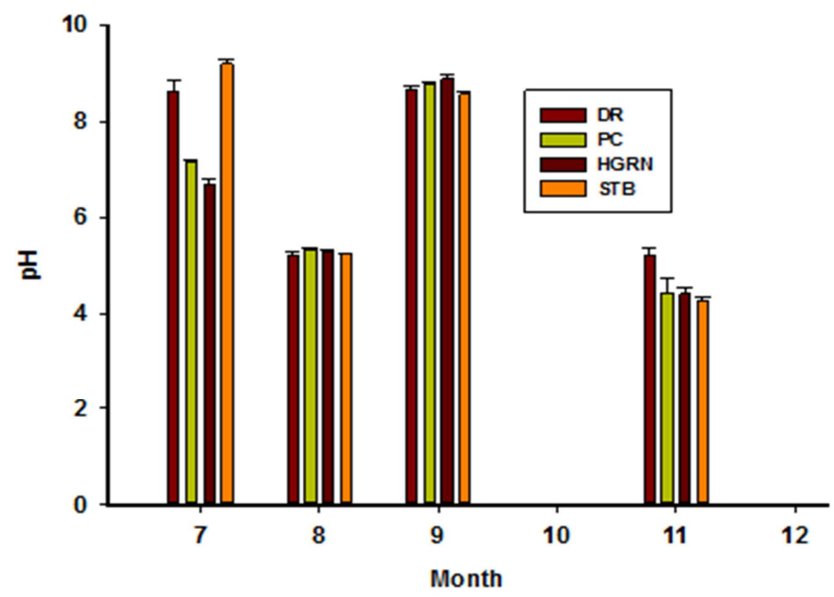

Figure 1. PH of wastewater from four differents sites in N'Djamena.

*DR: Diguel Ryad effluent, PC: Paris Congo effluent, HGRN: General Hospital effluent and STB: Chadian Brewery Company effluent.

\subsection{Temperature $\left({ }^{\circ} \mathrm{C}\right)$}

The results in figure 2 revealed that the wastewater has a temperature ranged on average between $\left(23.2-33.60^{\circ} \mathrm{C}\right)$. Temperatures higher than $30^{\circ} \mathrm{C}$ are not in accordance with wastewater discharging standards [26]. At location 1 (DR) and 2 (PC) temperatures ranged on average between $23.17 \pm$ $0.21^{\circ} \mathrm{C}$ in November to $32.27 \pm 0.40^{\circ} \mathrm{C}$ in July, while in site 3 (HGRN) and 4 (STB) the values were found to be $27.8 \pm$ $0.57^{\circ} \mathrm{C}$ in September and $33.60 \pm 0.10^{\circ} \mathrm{C}$ in July. The lowest temperature $\left(23.2^{\circ} \mathrm{C}\right)$ was recorded at location 2 in November, while the highest $\left(33.60^{\circ} \mathrm{C}\right)$ was recorded in July at location 4.

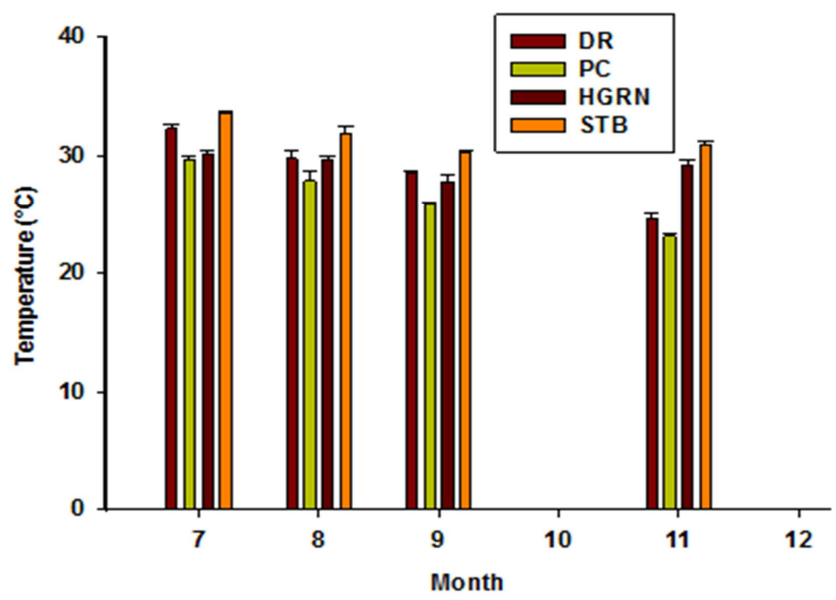

Figure 2. Temperature of wastewater from four different sites in N'Djamena.

\subsection{Electrical Conductivity}

Electrical conductivity is an important parameter used to evaluate pollution level in waste water. It depends on temperature and dissolved ions. From figure 3, highest and lowest values of electrical conductivity $(1997 \pm 10-212 \pm$ $0.01 \mu \mathrm{s} / \mathrm{cm}$ ) were recorded in September at location 4 (STB), and 2 (PC) respectively. The elevated values of electrical conductivity might be due to the presence of high soluble salts in the wastewater of Chadian Brewery Company, enhanced by the evaporation process. The death and migration of fishes at the wastewater discharge area of the Chadian Brewery Company into Chari River were reported [21].

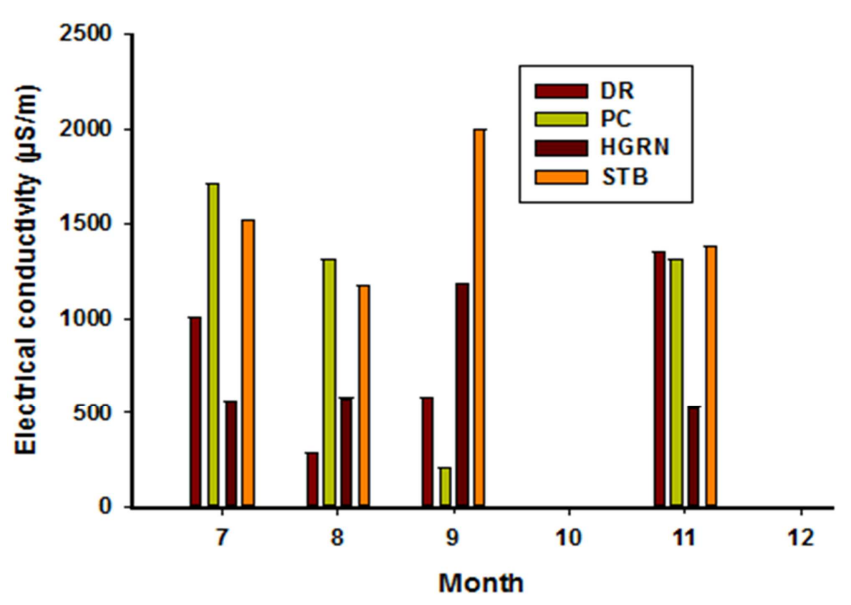

Figure 3. Electrical conductivity of wastewater from four different sites in N'Djamena.

\subsection{Total Dissolved Solids}

The total dissolved solids (TDS) represent the amount of organic and inorganic materials in a liquid in an ionic or molecular form. From figure 4, the highest average value $(906.63 \pm 1.21 \mathrm{mg} / \mathrm{l})$ of TDS in location 1 (DR) was recorded in November, while in location 2 (PC) was recorded in August $(877.48 \pm 2.35 \mathrm{mg} / \mathrm{l})$. Locations 3 (HGRN) and 4 (STB), scored the highest average values in September (791.82 $\pm 0.68,1338.1 \pm 0.84 \mathrm{mg} / 1$ respectively). The lowest value $(1.42 \pm 0.01 \mathrm{mg} / \mathrm{l})$ was recorded at locations 2 These results showed that site 4 record the highest value (1338.1 \pm $0.84 \mathrm{mg} / \mathrm{l}$ ) of total dissolved solids. This high value could be attributed to the concentration of soluble salts in the water exchange unit of the Chadian Brewery Company due to evaporation process.

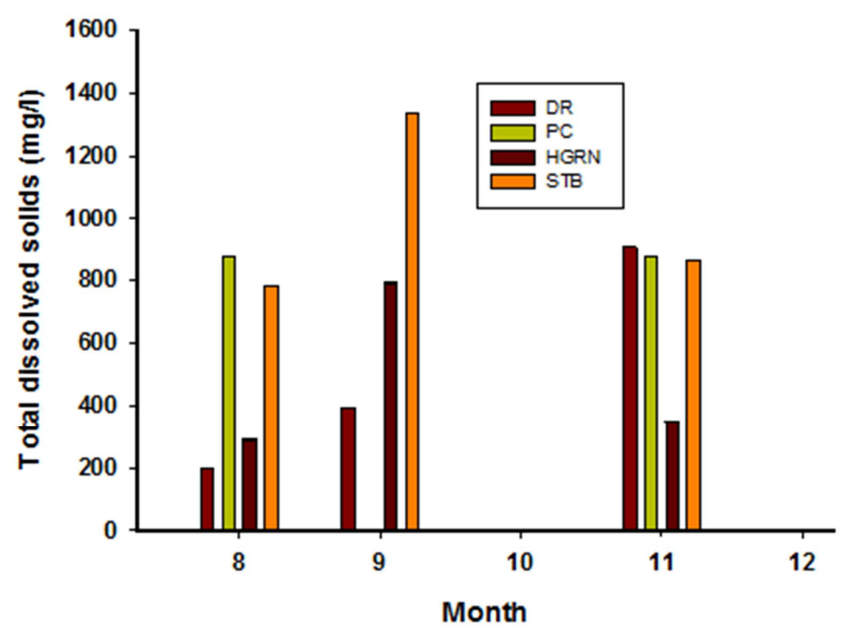

Figure 4. Total dissolved solids in wastewater from four different sites in N’Djamena. 


\subsection{Chemical Oxygen Demand (COD)}

As shown in Figure 5, the chemical oxygen demand (COD) was found to be $30.00 \mathrm{mg} / \mathrm{l}$ in August and $5380 \mathrm{mg} / \mathrm{l}$ in September in location 1 (DR). The rest of COD values fall within this range in locations 2 (PC), 3 (HGRN) and 4 (STB). The lowest values were recorded in August in locations 1, 2, 3 and $4(30,358,110,110 \mathrm{mg} / \mathrm{L}$ respectively), while the highest ones in locations 4, 3 and 2 were reported in July (1170 mg/L), September (1120 mg/L), and November (709 $\mathrm{mg} / \mathrm{L}$ ) respectively. From these results, it observed the majority of COD values reported are beyond the allowable limit $(75 \mathrm{mg} / \mathrm{L})$ recommended by World Health Organization standards for wastewater [27].

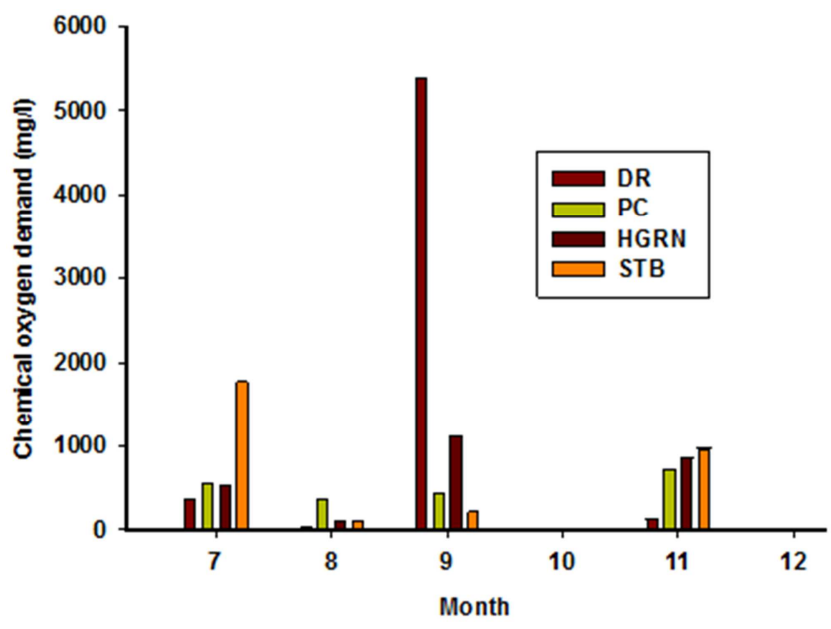

Figure 5. Chemical oxygen demand in wastewater from four different sites in N'Djamena.

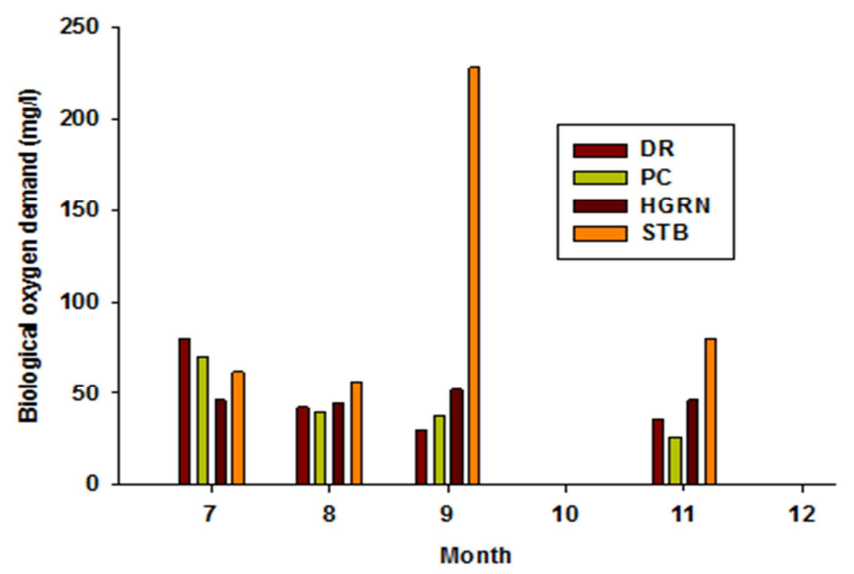

Figure 6. Biological oxygen demandin wastewater from four different sites in N'Djamena.

\subsection{Biological Oxygen Demand (BOD)}

As shown in Figure 6, the results of BOD showed varying concentrations in the four samples. The highest values recorded in July at locations $1(80.00 \mathrm{mg} / \mathrm{L})$ and $2(70.00 \mathrm{mg} / \mathrm{L})$, and in September at locations $3(52 \mathrm{mg} / \mathrm{L})$ and $4(228 \mathrm{mg} / \mathrm{L})$. While the lowest values for locations $1,2,3$ and 4 were found to be 30 $\mathrm{mg} / \mathrm{L}$ in September $\mathrm{mg} / \mathrm{L}, 26 \mathrm{mg} / \mathrm{L}$ in November, $44 \mathrm{mg} / \mathrm{L}$ in August and $56 \mathrm{mg} / \mathrm{L}$ in August respectively. These results suggested that the values of BOD during the study period were in the range of $26-228 \mathrm{mg} / \mathrm{L}$. However, the recommended limit of BOD in wastewater is $50 \mathrm{mg} / \mathrm{L}$ [28].

\subsection{Heavy Metals and Ions}

\subsubsection{Copper}

The copper content of wastewater samples varies dramatically in the 4 locations from $0.11 \mathrm{mg} / \mathrm{L}$ to $6.20 \mathrm{mg} / \mathrm{L}$. The result was shown in tables $1,2,3$ and 4 . In location 1 (DR) varied from $1.07 \mathrm{mg} / \mathrm{L}$ in July to $2.77 \mathrm{mg} / \mathrm{L}$ in November, in location 2 (PC) from $0.80 \mathrm{mg} / \mathrm{L}$ in August to $4.01 \mathrm{mg} / \mathrm{L}$ in September, in location 3 (HGRN) from 0.11 $\mathrm{mg} / \mathrm{L}$ in November to $1.06 \mathrm{mg} / \mathrm{L}$ in July and in location 4 (STB) from $1.41 \mathrm{mg} / \mathrm{L}$ in July to $6.20 \mathrm{mg} / \mathrm{L}$ in August. All these values of copper content are exceeded the WHO limit for irrigation water $(0.01-1.0 \mathrm{mg} / \mathrm{L})$. The elevated value of copper content in location 4 could be attributed to degradation of copper pipes used for the disposal of wastewater from Chadian Brewery Company directly into the Chari river.

\subsubsection{Zinc}

The results of analyzes of zinc concentration in the 4 samples are shown in the tables 1, 2, 3 and 4. The minimum values were recorded in November in location 1, 2, 3 and 4 as $0.02,0.31,0.02$, and $0.59 \mathrm{mg} / \mathrm{L}$ respectively, while the maximum concentrations were $1.01 \mathrm{mg} / \mathrm{L}$ (July), $2.65 \mathrm{mg} / \mathrm{L}$ (September), $0.89 \mathrm{mg} / \mathrm{L}$ (July) and $3.53 \mathrm{mg} / \mathrm{L}$ (August) in location 1, 2, 3 and 4 respectively. except the result of location $4(3.53 \mathrm{mg} / \mathrm{L})$, these results showed that the zinc content in the 4 samples are not exceed the limit permitted in wastewater $(3 \mathrm{mg} / \mathrm{L})$ [28].

\subsubsection{Manganese}

As shown in tables 1, 2, 3 and 4, the lowest manganese concentration was recorded in November. The lowest value $(0.003 \mathrm{mg} / \mathrm{L})$ was reported in September in location 1 , while the highest reported values in the location 1,2, 3 and 4 in August were 5.13, 6.77, 3.37 and $3.58 \mathrm{mg} / \mathrm{L}$ respectively. The maximum limit allowed of heavy metals in waste water is $6.61 \mathrm{mg} / \mathrm{L}$ [28].

\subsubsection{Aluminum}

The result of aluminum concentration in the different samples studied were figured in the tables $1,2,3$ and 4 . The lowest values $(0.10,0.00$ and $0.13 \mathrm{mg} / \mathrm{L})$ were recorded in November in locations 2, 3 and 4 respectively, all of which are within the allowable limit for drinking water $(0.2 \mathrm{mg} / \mathrm{L})$ [29-30], while the result in location $1(0.98 \mathrm{mg} / \mathrm{L})$ in September was beyond this limit. The highest values in positions 1, 2, 3 and 4 were: $1.11 \mathrm{mg} / \mathrm{L}$ in November, 1.11 $\mathrm{mg} / \mathrm{L}$ in July, $0.28 \mathrm{mg} / \mathrm{L}$ in August and $0.51 \mathrm{mg} / \mathrm{L}$ in September respectively, all of which are exceed the allowable limit, except in Location $3(0.18 \mathrm{mg} / \mathrm{L})$. The highest value of aluminum concentration $(1.12 \mathrm{mg} / \mathrm{L})$ was recorded in July in Location 2. The elevated concentration of aluminum could be attributed to accumulation of waste water from traditional fabrication of kitchen aluminum tools in location 1 . 


\subsubsection{Iron}

The results of analyzes of iron concentration in the samples are shown in the tables 1, 2, 3 and 4. All readings recorded are exceeded the allowable limit in drinking water $(0.05-0.20 \mathrm{mg} / \mathrm{L})[31]$ as well as in wastewater $(0.3 \mathrm{mg} / \mathrm{L})$ [27]. In location 1 (DR) the readings are varied from 1.90 $\mathrm{mg} / \mathrm{L}$ in August to $4.20 \mathrm{mg} / \mathrm{L}$ in November, while in location 2 (PC) from $5.92 \mathrm{mg} / \mathrm{L}$ in July to $0.90 \mathrm{mg} / \mathrm{L}$ in November. In location 3 (HGRN) and 4 (STB) the lowest values were recorded in September $(0.39,2.30 \mathrm{mg} / \mathrm{L})$ and the highest ones were recorded in July and August $(3.43,3.11 \mathrm{mg} / \mathrm{L}$ ) respectively. The elevated value of ion content in location 2 could be attributed to degradation of useless iron pots thrown without any health control.

\subsection{Dissolved Ions}

\subsubsection{Bicarbonate}

The results of analyzes of bicarbonate concentrations in all samples studied are shown in the tables (1, 2, 3 and 4). The lowest bicarbonate concentration $(23.67 \mathrm{mg} / \mathrm{L})$ was recorded at location 3 (HGRN) in August, while highest one $(853.33 \mathrm{mg} / \mathrm{L})$ was recorded at the same location in September. At location 1 (DR) the values are varied from $203.33 \mathrm{mg} / \mathrm{L}$ in July to $363.00 \mathrm{mg} / \mathrm{L}$ in November, whereas at location 2 (PC) the readings varied from $344.00 \mathrm{mg} / \mathrm{L}$ in August to $750.33 \mathrm{mg} / \mathrm{L}$ in September. At location $4(\mathrm{STB})$ the highest value $(646.67 \pm 2.89 \mathrm{mg} / \mathrm{L})$ was recorded in September and the lowest one $(307.00 \pm$ $2.65 \mathrm{mg} / \mathrm{L}$ ) was recorded in November. Most of these results are exceeded the recommended limit $(130 \mathrm{mg} / \mathrm{L})$ for drinking water [27]. These high bicarbonate concentrations in the samples studied could be attributed to the concentration of bicarbonate salts due to evaporation of water in hot season.

\subsubsection{Phosphate}

As shown in tables 1, 2, 3 and 4, the phosphate profile ranged from 0.023 to $333.67 \mathrm{mg} / \mathrm{L}$ at the four study locations. At location 1 (DR) the values are varied from $0.399 \mathrm{mg} / \mathrm{L}$ in November to $45.97 \mathrm{mg} / \mathrm{L}$ in August, while in location 2 (PC) from $0.023 \mathrm{mg} / \mathrm{L}$ in November to $333.67 \mathrm{mg} / \mathrm{L}$ in September. At location 3 (HGRN) and 4 (STB) the lowest values were recorded in November $(0.05,0.67 \mathrm{mg} / \mathrm{L})$ and the highest ones were recorded in July as 66.00 and $213.33 \mathrm{mg} / \mathrm{L}$ respectively. These results showed that the phosphate concentrations in wastewater are exceeded the recommended limit $(10 \mathrm{mg} / \mathrm{L})$ [32], and this could be due to the relatively acidic nature of wastewater in the mentioned period. This acidic medium does not favorize the deposition of phosphate ions in form of calcium, magnesium or generally heavy metals phosphate, which are slightly soluble in water [33]. The increase of phosphor in wastewater encourages the growth of algae and hence increases the percentage of plant nutrients in water [34].

\subsubsection{Nitrate}

Generally, the nitrate concentrations in the four samples studied are ranged from 0.98 to $127.0 \mathrm{mg} / \mathrm{L}$. The lowest values at locations 1 (DR), 2 (PC) and 3 (HGRN) were recorded in July as $0.98,2.92$ and $1.98 \mathrm{mg} / \mathrm{L}$ respectively, while at location 4 (STB), the lowest value $(8.40 \mathrm{mg} / \mathrm{L})$ was recorded in November. The highest values of nitrate concentrations at locations $1,2,3$ and 4 were found to be $23.0 \mathrm{mg} / \mathrm{L}$ in August, $38.27 \mathrm{mg} / \mathrm{L}$ in September, 31.70 $\mathrm{mg} / \mathrm{L}$ in August, and $127.0 \mathrm{mg} / \mathrm{L}$ in July $\mathrm{mg} / \mathrm{L}$ respectively, all of which are exceeded the recommended limit (1-10 $\mathrm{mg} / \mathrm{L})$ in drinking water [35] as well as in wastewater $(15 \mathrm{mg} / \mathrm{L})$ [27]. This highest nitrate concentration recorded in the sample of Beverage plant (location 4) could be attributed to the presence of organic and inorganic nitrogenic maters in the sewage, as well as dust and other substances that could reach the drainage channel of the plant. Also, this high nitrate concentration could be due to the lack of oxygen content of organic matter in wastewater [36].

Table 1. Heavy metals and dissolved ions in wastewater of Diguel Ryad (DR) channel.

\begin{tabular}{|c|c|c|c|c|c|c|c|c|}
\hline \multicolumn{9}{|c|}{ Heavy metals and ions (mg/l) } \\
\hline Month & $\mathrm{Cu}$ & $\mathbf{Z n}$ & Al & $\mathbf{F e}$ & Mn & $\mathrm{NO}_{3}^{-}$ & $\mathrm{PO}_{4}{ }^{3-}$ & $\mathrm{HCO}_{3}^{-}$ \\
\hline July & $1.07 \pm 0.02$ & $1.01 \pm 0.01$ & $0.21 \pm 0.02$ & $2.56 \pm 0.02$ & $0.01 \pm 0.001$ & $1.98 \pm 0.02$ & $2.80 \pm 0.44$ & $203.33 \pm 2.89$ \\
\hline September & $1.10 \pm 0.04$ & $0.60 \pm 0.07$ & $007 \pm 0.01$ & $1.99 \pm 0.02$ & $0.003 \pm 0.00$ & $18.10 \pm 0.70$ & $33.50 \pm 1.15$ & $300.33 \pm 0.58$ \\
\hline November & $2.77 \pm 0.04$ & $0.02 \pm 0.01$ & $0.20 \pm 0.01$ & $4.20 \pm 0.10$ & $0.004 \pm 0.00$ & $6.93 \pm 0.06$ & $0.67 \pm 0.03$ & $363.00 \pm 2.65$ \\
\hline Average & 1.55 & 0.64 & 0.16 & 2.66 & 1.29 & 12.50 & 20.74 & 268.58 \\
\hline
\end{tabular}

Table 2. Heavy metals and dissolved ions in wastewater of Paris Congo (PC) channel.

\begin{tabular}{|c|c|c|c|c|c|c|c|c|}
\hline \multicolumn{9}{|c|}{ Heavy metals and ions (mg/l) } \\
\hline Month & $\mathrm{Cu}$ & Zn & Al & $\mathrm{Fe}$ & Mn & $\mathrm{NO}_{3}^{-}$ & $\mathrm{PO}_{4}{ }^{3-}$ & $\mathrm{HCO}_{3}^{-}$ \\
\hline July & $2.57 \pm 0.02$ & $1.01 \pm 0.01$ & $1.12 \pm 0.02$ & $5.92 \pm 0.02$ & $0.02 \pm 0.002$ & $2.92 \pm 0.02$ & $225.33 \pm 0.58$ & $339.67 \pm 0.58$ \\
\hline August & $0.80 \pm 0.01$ & $1.23 \pm 0.04$ & $1.11 \pm 0.03$ & $2.72 \pm 0.01$ & $6.77 \pm 0.42$ & $24.90 \pm 0.10$ & $44.13 \pm 0.61$ & $344.00 \pm 1.73$ \\
\hline September & $4.01 \pm 0.01$ & $2.65 \pm 0.03$ & $0.44 \pm 0.01$ & $4.73 \pm 0.02$ & $0.012 \pm 0.001$ & $38.27 \pm 0.05$ & $333.67 \pm 1.25$ & $750.33 \pm 0.47$ \\
\hline November & $1.21 \pm 0.01$ & $0.31 \pm 0.01$ & $0.10 \pm 0.01$ & $0.92 \pm 0.02$ & $0.00 \pm 0.00$ & $6.33 \pm 0.31$ & $0.05 \pm 0.01$ & $403.67 \pm 2.62$ \\
\hline Average & 2.15 & 1.30 & 0.70 & 3.56 & 1.70 & 18.11 & 150.80 & 459.42 \\
\hline
\end{tabular}


Table 3. Heavy metals and dissolved ions in wastewater of Reference General Hospital (HGRN) channel.

\begin{tabular}{lllllllll}
\hline Heavy metals and ions (mg/l) & & & & & & \\
\hline Month & $\mathbf{C u}$ & $\mathbf{Z n}$ & $\mathbf{A l}$ & $\mathbf{F e}$ & $\mathbf{M n}$ & $\mathbf{N O}_{3}{ }^{-}$ & $\mathbf{P O}_{4}{ }^{-{ }^{-}}$ & $\mathbf{H C O}_{3}{ }^{-}$ \\
\hline July & $1.06 \pm 0.01$ & $0.89 \pm 0.01$ & $0.28 \pm 0.01$ & $3.43 \pm 0.03$ & $0.010 \pm 0.001$ & $0.98 \pm 0.02$ & $66.00 \pm 0.87$ & $29.67 \pm 0.58$ \\
August & $0.66 \pm 0.02$ & $0.26 \pm 0.01$ & $0.18 \pm 0.01$ & $0.54 \pm 0.01$ & $3.37 \pm 0.30$ & $31.70 \pm 0.10$ & $34.56 \pm 0.46$ & $23.67 \pm 1.15$ \\
September & $0.52 \pm 0.01$ & $0.17 \pm 0.01$ & $0.013 \pm 0.01$ & $0.39 \pm 0.01$ & $0.000 \pm 0.00$ & $9.47 \pm 0.38$ & $18.17 \pm 0.19$ & $853.00 \pm 1.63$ \\
November & $0.11 \pm 0.01$ & $0.02 \pm 0.01$ & $0.00 \pm 0.00$ & $0.47 \pm 0.02$ & $0.000 \pm 0.00$ & $3.57 \pm 0.24$ & $0.023 \pm 0.01$ & $305.67 \pm 2.62$ \\
Average & 0.59 & 0.34 & 0.09 & 1.21 & 0.85 & 11.43 & 29.69 & 303.00 \\
\hline
\end{tabular}

Table 4. Heavy metals and dissolved ions in wastewater of Chadian Brewery Company (STB) channel.

\begin{tabular}{|c|c|c|c|c|c|c|c|c|}
\hline \multicolumn{9}{|c|}{ Heavy metals and ions (mg/l) } \\
\hline Month & $\mathbf{C u}$ & $\mathbf{Z n}$ & Al & $\mathbf{F e}$ & Mn & $\mathrm{NO}_{3}^{-}$ & $\mathrm{PO}_{4}{ }^{3-}$ & $\mathrm{HCO}_{3}^{-}$ \\
\hline July & $1.41 \pm 0.01$ & $0.76 \pm 0.01$ & $0.21 \pm 0.02$ & $3.11 \pm 0.01$ & $0.01 \pm 0.001$ & $127.00 \pm 1.00$ & $213.33 \pm 2.89$ & $351.67 \pm 1.53$ \\
\hline August & $6.20 \pm 0.27$ & $3.53 \pm 0.06$ & $0.22 \pm 0.01$ & $13.11 \pm 0.01$ & $3.58 \pm 0.04$ & $64.43 \pm 0.51$ & $139.00 \pm 1.00$ & $353.33 \pm 1.53$ \\
\hline September & $1.67 \pm 0.01$ & $0.73 \pm 0.02$ & $0.51 \pm 0.02$ & $2.30 \pm 0.01$ & $0.003 \pm 0.001$ & $10.67 \pm 0.15$ & $78.67 \pm 0.58$ & $646.67 \pm 2.89$ \\
\hline November & $3.70 \pm 0.30$ & $0.58 \pm 0.01$ & $0.13 \pm 0.01$ & $3.38 \pm 0.03$ & 0.0 & $8.40 \pm 0.44$ & $0.39 \pm 0.03$ & $307.00 \pm 2.65$ \\
\hline Average & 3.25 & 1.40 & 0.27 & 5.48 & 0.90 & 52.63 & 107.85 & 435.11 \\
\hline
\end{tabular}

\section{Conclusion}

The production of healthy agricultural vegetables remains challenge in parts of the capital of Chad, N'Djamena. The irrigation of the mentioned products by untreated wastewater become habitual practice without any a warning from the concerned officers. The current study assessed some physical and chemical characteristics of wastewater used to irrigate legumes and vegetables consumed daily in N'Djamena city in Chad and evaluate their environmental impact. The results revealed that the values of $\mathrm{pH}, \mathrm{Zn}$ and $\mathrm{Mn}$ were within the recommended limits for most of the sampling period and ranged between $4.26-8.57,0.02-3.53 \mathrm{mg} / \mathrm{L}$ and $0.003-$ $6.77 \mathrm{mg} / \mathrm{L}$, respectively, while the values of temperature, electrical conductivity EC, total dissolved solids TDS, chemical oxygen demand COD, biological oxygen demand $\mathrm{BOD}, \mathrm{Cu}, \mathrm{Al}, \mathrm{Fe}$, bicarbonate, phosphate and nitrate, were exceeded the recommended limits. These results confirmed the deterioration of physicochemical qualities of the discharged wastewater effluents (Diguel Ryad (DR) quarter in the municipal 8, Site 1; Paris Congo (PC) quarter in the municipal 7, Site 2; General Hospital Channel (HGRN) in the municipal 3, Site 3 and the Chadian Brewery Company Channel (STB) Farcha quarter, in the municipal 1, Site 4). Our findings require urgent intervention of the Chadian government to reduce the risk of indiscriminate pollution of environments through the continuous and irresponsible release of untreated effluents from different private and public sectors in the N'Djamena city in order to avoid public health concerns associated with environmental pollution.

\section{Acknowledgements}

This work is partially financed by Chad Government, through CONFOFOR scholarship, funded by the president of the Republic of Chad, His Excellency the Marshal of Tchad IDRIS DEBY INTO.

\section{References}

[1] Alobaidy A. M. J., Al-Sameraiy M. A., Kadhem A. J., Athmar A., (2010). Evaluation of Treated Municipal Wastewater Quality for Irrigation. Journal of Environmental Protection, 1, 216-225.

[2] Morari F., Giardini L., (2009). Municipal Wastewater Treatment with Vertical Flow Constructed Wetland for Irrigation Reuse. Ecological Eng., 35, 643-653.

[3] Magdalena Loj-Pilch, Anita Zakrzewska, (2020). Analysis of Risk Assessment in a Municipal Wastewater Treatment Plant Located in Upper Silesia. Water, 12-23.

[4] Levantesi C., La Mantia R., Masciopinto C., Böckelmann U., Ayuso Gabella M. N., Salgot M., Tandoi V., Van Houtte E., Wintgens T., Grohmann E., (2010). Quantification of pathogenic microorganisms and microbial indicators in three wastewater reclamation and managed aquifer recharge facilities in Europe. Science of the Total Environment, 408, 4923-4930.

[5] Abdallah Bakhit S., (2014). N'Djamena town "Analytical and applied study on town's geography”, Ph.D, Africa International University, Sudan.

[6] Moukhtar Abderahman, S., (2008). Environmental pollution in N'Djamena town "Applied study on the current situation", M.Sc., Academy of Higher Studies, Libya.

[7] Tchadanaye N. M., Noumi G. B., Paloumi Yabe., (2016) Pollution of the Chari River in the Slaughterhouse Farcha (N'djamena) in Chad, American Journal of Environmental Protection, 5 (1), 11-19.

[8] Bantin A. B., Jun X., (2017). Assessment of Environmental risks related to the release of industrial and domestic toxic waste in the aquatic environment of chad. Environ Risk Assess Remediation, 1 (3), 22-25.

[9] Mosse K. P. M., Patti A. F., Smernik R. J., Christen E. W. Cavagnaro T. R., (2012). Physicochemical and microbiological effects of long- and short-term winery waste water application to soil, Journal of Hazardous Materials, 30, 219-228. 
[10] Pednekar A. M., Grant S. B., Jeong Y., Poon Y., Oancea C., (2005). Influence of climate change, tidal mixing, and watershed urbanization on historical water quality in Newport Bay, a saltwater wetland and tidal embayment in southern California, Environ Sci Technol, 39, 9071-9082.

[11] Oster, J. D., (1994). Irrigation with Poor Quality Water, Agricultural Water Management, 25 (3), 271-297.

[12] Qadir M., Wichelns D., Raschid-Sally L., Minhas P. S., Drechsel P., Bahri A., McKornick P., (2007). Agricultural Use of Marginal Quality Water Opportunities and Challenges, In: D. Molden, Ed., Water for Food, Water and life: A Comprehensive Assessment of Water Management in Agriculture, Earthscan, London.

[13] Rabea E., Bahia B., Youssef M., Ahlam F., El Mouhri G., Bouchra O., Khatouf M., Karima E., Touimi G. B., Anissa L., (2019). Microbiological and Physicochemical Characterization of Hospital Effluents before and after Treatment with Two Types of Sawdust, Journal of Chem., Doi.org/10.1155/2019/3275101.

[14] WHO, (2006). Health Guidelines for the Use of Wastewater in Agriculture and Aquaculture, Report of a WHO Scientific Group, Geneva.

[15] Benit N., Stella Roslin A., (2015). Physicochemical properties of wastewater collected from different sewage sources. International Journal of Innovative Science, Engineering \& Technol., 2 (11), 691- 696.

[16] Mojeed A. A., Okoh O. O., Adefisoye M. A., Anthony I. O., (2018). Physicochemical Properties of Wastewater in Three Typical South African Sewage Works, Pol. J. Environ. Stud., 27 (2), 491-499.

[17] Xiaochang W., Pengkang J., Hongmei Z., Lingba M., (2007). Classification of contaminants and treatability evaluation of domestic wastewater, Front. Environ. Sci. Eng., 1 (1), 57-62.

[18] Knechtel R. J., (1978). A more economical method for the determination of chemical oxygen demand, Water Pollution Control, 25-29.

[19] Lorduy-Tarón A. S., Marín-Gongora, Taron-Dunoyer A., (2019). Wastewater Physicochemical Characterization from the Thanatopraxy Room, Contemporary Engineering Sciences, 12 (2), 65 - 71.

[20] Altidjani-Hisseine A., Kamga R., Tchadanaye N. M., (2016). Physico-Chemical Evaluation of Wastewater from Abattoir, Brewery, Soap and Oil Factories, at Moundou City in Southern Chad, Int. Journal of Engineering Research and Applications, 6 (1), 19-30.

[21] N'garam N., Clement Y., Merle A., Tchadanaye N. M. Lanteri P., (2017). Heavy Metal Pollution of Chari River water during the Crossing of N'Djamena (Chad), Toxics, Doi: 10.3390/toxics5040026.
[22] AFNOR M. T., (1995). Water quality changes at lake Monger due to widening of the Michell freeway CSIRO, Western Australia, Progress report the Main Roads Department.

[23] ISO 2100P., (2006). Wastewater characterization for evaluation of Turbidity in Water and Wastewater. USA, 84-92.

[24] American Public Health Association (APHA), (2005). Standard Methods for the Examination of Water and Wastewater 21th ed. Washington, D.C.

[25] United Stats Environmental Protection Agency (USEPA, (1979). Guidelines for Wastewater used in irrigation, Volume 7.

[26] AFNOR, (1994). French Association of Normalization, Quality of the water and the environment, France, 862p.

[27] WHO, (1993). Guidelines for Quality Wastewater used in irrigation, Vol. 3: Recommendations WHO, Geneva.

[28] Mustapha I. H., Adeboye Omotayo B., (2014). Heavy metals accumulation in edible part of vegetables irrigation with untreated municipal wastewater in Tropical Savannah Zone Nigeria, African Journal of Environmental sciences and Technology, 47-58.

[29] Official Gazette No. 5062, (2002). dated 30 Ramadan 1423 (5 December) laying down the standards of water quality for irrigation.

[30] Chaouki H., Elwatik L., Fath-Allah R., Ayyach A., Fathallah Z., El Midaoui A., (2014). Evaluation of the content of heavy metals and organic micropollutantsin the effluents of the wastewater treatment plant of the Errachidia city-Morocco. Int. Journal of Engineering, Research and Applications, 4 (6), 28-32.

[31] European Union (EU), (2011). Guidelines for Quality Wastewater used in irrigation, pp 14.

[32] Moroccan Standards, (2002). Limit values of direct and indirect discharges of Morocco, Ministry of Environment of Morocco. Official Bulletin of Morocco, No. 5062 of 30 Ramadan 1423. Rabat.

[33] Tolulope E. A., Temilola Oluseyi, John O. O., Edokpayi J. N., (2019). Physico-Chemical Analysis of Wastewater Discharge from Selected Paint Industries in Lagos, Nigeria. Int. J. Environ. Res. Public Health, 16: doi: 10.3390/ijerph16071235.

[34] Al-salman A. M., (1985). Analytical studies on some ions in wastewater treatment and use in irrigation at al-gatroun City, M.Sc., Fac. Sci. Sabha. Univ, 12-21.

[35] Hashem M. S., Xuebin Qi., (2021). Treated Wastewater IrrigationA Review, Water, 13: 1527, doi.org/10.3390/w13111527.

[36] Okey R. W., Albertson O. E., (1989). The role of the diffusion in regulating rate and masking temperature effects on fixed film nitrification. J. Water pollution control Fed, 61, 170-176. 